\title{
Digitalization - relationship with the research area and education. One of the principal strategic directions of growth of agricultural land users
}

\author{
Digitalización - Relación con el área de investigación y educación. Una de las principales \\ direcciones estratégicas del crecimiento de los usuarios de tierras agrícolas
}

DYACHKOV Valery P. ${ }^{1}$

SOFINA Elena V. ${ }^{2}$

\begin{abstract}
The article reveals a new structure for the implementation of the electronic textbook for the study of the discipline "Financial Management" in the form of a system of electronic educational complexes (EEC). This system includes twelve independent electronic educational complexes, each of which consists of five modules necessary for studying new material, developing practical skills in applying theoretical knowledge based on problem solving, and also testing generated competencies through testing.

Key words: digitalization of the economy; electronic textbook structure; electronic educational complex.

Resumen

El artículo revela una nueva estructura para la implementación del libro de texto electrónico para el estudio de la disciplina "Gestión Financiera" en forma de un sistema de complejos educativos electrónicos (CEE). Este sistema incluye doce complejos educativos electrónicos independientes, cada uno de los cuales consta de cinco módulos necesarios para estudiar nuevo material, desarrollar habilidades prácticas para aplicar el conocimiento teórico basado en la resolución de problemas y también evaluar las competencias generadas a través de las pruebas.

Palabras clave: digitalización de la economía; estructura electrónica de libros de texto; complejo educativo electrónico.
\end{abstract}

\section{Introduction}

Current capabilities of the use of information technologies allow the students to manage their teaching and learning activities and to learn the educational material in a more efficient way. Electronic educational complexes (EEC) belong to such instruments for the management of independent work; these complexes shall be understood as teaching aids which combine learning fundamental material, solving practical and test tasks, as well as doing independent work. The main advantage of the EEC consists in the unification of the textbook on

\footnotetext{
${ }^{1}$ Vyatka State Agricultural Academy, Kirov, Russia, E-mail: d-v-p53@mail.ru

${ }^{2}$ Vyatka State Agricultural Academy, Kirov, Russia, Federal Research Center of Agrarian Economics and Social Development of Rural Territories - AllRussian Research Institute of Agricultural Economics, Moscow, Russia, Vyatka State University, Kirov, Russia, e-mail: evsofina@mail.ru
} 
the discipline, technology for the completion of various educational tasks and proficiency examination tasks in a single shell (Dyachkov, 2015). This being said, the educational process can be carried out both in the classroom and remotely - by means of Beclever testing system (Dyachkov, 2018).

The system of electronic educational complexes (SEEC) includes a set of resources for eleven classroom disciplines which were developed in the Vyatka State Agricultural Academy and posted in the local intranet at: http://euk.vgsha.local, which can only be accessed so far by Academy students - from computer rooms, and teachers - from personal computers of the Department.

The access process is reduced to the following operations: 1) launch any browser, such as Opera or Google Chrome, where you need to type the above access address in the address bar: http://euk.vgsha.local; 2) in the window that appears, from the list of areas of study (specialties): Bachelor's degree, Master's degree, Specialist's degree, Postgraduate training program, College, select the option you need; 3) the following Web page shows all the faculties of the Academy: Agronomy, Biology, Veterinary Medicine, Engineering, Economics; 4) select Management from the list of areas of study; 5) select Financial Management from the list of disciplines; 6) choose a topic to study.

\section{Methodology}

The EEC system for the discipline "Financial Management" in Androshchuk et al. (2018), Basova et al. (2018), Weizner et al. (2018), Vidyakina (2018), Vyrupaeva ,et al. (2018), Konysheva et al. (2018), Listopad et al. (2018), Naumova et al. (2018), Polushina et al. (2018), Rykova et al. (2018), Semenova et al. (2018) has been developed under the supervision of the Candidate of pedagogic sciences, Associate Professor of the Department of information technologies and statistics Valery P. Dyachkov, and Candidate of economic sciences, Associate Professor of the Department accounting and finance Elena V. Sof'ina, and the students of our Academy with a specialization in "Finance and credit" in academic year 2013-2014: Elena V. Androshchuk, Alyona V. Basova, Yuliya A. Vaitsner, Alyona S. Vidyakina, Natalya S. Vyrupaeva, Maria E. Konysheva, Nadezhda V. Listopad, Anastasia A. Naumova, Yuliana N. Polushina, Lyudmila S. Rykova, Ekaterina L. Semenova, and were tested and refined in the following years

As an example, we shall take our experience of work with students in Financial Management classes with the use of the EEC on the topic "Maximization of profitability of agricultural enterprises of the region" (developed by the student Androshchuk, E.V.), which includes five modules: 1) Theory, 2) Practice, 3) Independent Works, 4) test tasks and 5) technology of management of resource (Dyachkov, 2012). We shall consider each of these modules in more detail.

\section{Results}

Theory module presents the subject matter of the main notions and terms, without knowledge of which it is impossible to learn the practical educational material. During the study of the theory of business costs, educational material is subdivided into two sections, the first of which consists of the comprehension of the category of costs and the study of costs in the short run, and the second one consists in the analysis of costs in the long run and considering economies of scale. The subject matter of the theoretical part of the complex consists of the following topics:

Topic 1, "Short-term and long-term goals of the enterprise", reveals the essence of category "Short-term and long-term goals", demonstrates what these goals are aimed at, explains what factors contribute to the emergence of "bottlenecks" at the enterprise. 
Topic 2, "Subject-matter, indicators and profitability ratios", briefly reveals the essence of profitability, calculation formulas.

Topic 3, "Profitability formation management" defines profitability as a system and explains its subsystems, briefly shows the varieties of profitability management methods, as well as the basic Dupont model, shows the profitability analysis and calculation formulas.

Topic 4, "Break-even point (point of make-out)", explains the concept of breakeven point, types of costs and their varieties, explains the break-even condition of the enterprise, calculation formulas.

Topic 5, "Interaction of financial leverage and operating leverage", shows semi-fixed costs and variable costs of production and financial nature; shows that it determines the level of operating leverage and financial leverage; all of the above leads to the understanding of the business risk that characterizes all aspects of activities of the enterprise; calculation formulas.

Topic 6, "Reduced profitability prevention", shows prevention as a component of anti-crisis financial management of the enterprise and activities to maintain target standards.

Topic 7, "Securities management policy of the enterprise", shows directions of financial policy with regard to capital formation or investment of finance; shows the goal of forming a securities portfolio and insuring it against risks, explains technical securities transactions.

Topic 8, "Bill of exchange transactions", shows the ways of using corporate securities as a constituent element of financial policy of the enterprise.

Topic 9, "Determining the yield on securities", shows the total yield on securities, effective yield on corporate securities, yield on securities portfolio, and calculation formulas.

Topic 10, "The impact of inflation on profitability", explains the impact of inter-temporal changes in costs and revenues on fluctuations of profitability and final performance results of the enterprise, presents the idea of the real yield rate in the context of inflation, using I. Fisher's formula, inflation premium.

Brief conclusions on the topics are drawn in "Conclusion".

"Glossary" contains the list of the main notions and terms with corresponding definitions. When the EEC is first mentioned in the text, hyperlink is made to the "Glossary", and when the student follows this link, he well be able to get acquainted with complete definition of this notion or term, and then use other hyperlink to return to the same point in the text from which he went to the "Glossary". Such method of study of new notions and terms simplifies the procedure of acquaintance with definitions contained in the electronic resource.

"Reference list" includes twenty sources that were used in the creation of the EEC.

In the Practice module, the students must use their theoretical skills in the process of completion of practical tasks of calculation of business costs. This module gives the definition of the upcoming task and gives a detailed description of its solution. Overall, this module provides for the solution to several practical tasks aimed at calculating certain types of costs in the short run and in the long run. Each task starts with the definition of initial data and questions, i.e. what needs to be done. Then a step-by-step solution to the task is presented with the formulation of answers. The subject matter of all tasks is aimed at reinforcing the learned material on a particular section of the studied topic.

We shall give consideration to the types of operations that are formed in each of ten practical works. 
Practice 1, "Short-term and long-term goals of the enterprise", offers one task of calculating a short-term credit to increase current assets of the enterprise

Practice 2, "Subject-matter, indicators and profitability ratios", provides for the solution to the task of determining the profitability of current assets.

Practice 3, "Profitability formation management", allows training students in determining the profit corresponding to a new level of revenue from sales using the traditional method and using the operating lever, and draw conclusions from results obtained.

Practice 4, "Break-even point (point of make-out)" is aimed at identifying the break-even point, the critical revenue position, and the minimum number of products to which they correspond.

Practice 5, "Interaction of financial leverage and operating leverage" builds skills to determine net profit per share.

Practice 6, "Reduced profitability prevention" demonstrates how one can identify the operating efficiency of the enterprise in terms of product profitability. The calculations are presented in the form of the Table, which increases the clarity and transparency of the actions performed.

Practice 7, "Securities management policy of the enterprise", solves a task of determining the amount of dividend that will be paid for each stock of the joint-stock company.

Practice 8, "Bill of exchange transactions", average debit indebtedness is calculated, the amount of money which the enterprise will receive with the use of factoring, and determining the efficient annual cost of factoring.

Practice 9, "Determining the yield on securities", gives an example of calculation of yield on bonds for two years.

Practice 10, "The impact of inflation on profitability", presents the calculation of the rate of inflation, the nominal interest rate on capital, and the total amount adjusted for inflation.

In the Independent Work module, the students perform their tasks based on the study of the Theory module and based on the training exercises of the Practice module, but through their individual effort this time, think over the sequence of procedures for the solution of specific tasks. All topics of independent works coincide with topics of the practice module. Unlike this module, there are no detailed instructions on how a particular transaction is performed, and the students need to think through and perform the entire sequence of actions required to solve the task all by themselves. In order to verify the correct solution to the completed task, when the work is performed not in the classroom, but independently, for example, in case of homeschooling, the answers to them are given. One can go to answers by pressing the "Result" button, which is located in the bottom part of each page. One can return to the task by pressing the "Back" button. In some cases, when the task is rather time-consuming and the probability of error is high, in the independent work on a sheet of paper; as a result, complete solution to the task may be presented.

Tests module includes a set of test tasks on the studied issues and topics, as well as the final test compiled on the basis of the tasks on the topics. Tests on the topics may contain four types of test tasks: 1) with one correct answer, 2) with two or three correct answers, 3) for ordered sequence and 4) for correspondence. The number of tasks of each type is determined by the content of fundamental material and the need for the formation of a particular structure of the final test. The total number of tasks does not exceed fifty. The tasks for the final test are chosen from tests on the topics, but the arrangement of correct answers in them differs from the arrangement in the tests on the topics. This is an essential requirement when creating the EEC. 
Test tasks are drawn up in such a way as to cover the most important notions and skills that have a significant impact on the formation of professional competencies contained in the State Standard in the discipline "Financial Management".

The final test on the topic "Maximization of profitability of agricultural enterprises of the region" - includes test tasks from the tests by separate paragraphs and topics. These tasks are selected on the ground of their importance and significance for the learning of this topic.

The last module in the resource is the "Technology" of management of content of this resource. It includes the description of completion sequence for all elements of the complex and gives a student the right to choose the sequence of the study of the educational material. The EEC provides for three methods of learning the educational material: 1 ) sequential linear - the whole theory is studied, then all training exercises are performed, and creative tasks for independent work as well as testing on the topics are completed; 2 ) sequential non-linear - completion of the theory, performance of practical and independent works on the same topic only; 3 ) arbitrary - completion in any order at the discretion of the student. Such arrangement allows the user to choose the necessary topic to study, and to set the type of work performed: the study of the theory, performing exercises and creative tasks or testing on the topics, as well as convenient navigation (completion sequence) through the web resource.

When the first option is chosen, a consistent linear study is performed by pressing the "Forward" button only, which is present on each web page of the complex (located below). In the second option - during sequential non-linear training - after the theoretical part is completed, the student performs exercises and independent works or solves test tasks by pressing the "Up" button (located at the bottom of the Web page) and operation mode selection: Practice, Independent Work, Tests (located at the top of the Web page). The third option arbitrary - involves using all navigation buttons: "Forward" (go to the next page), "Back" (return to the previous page), instantly moving to the top of the page using the "Up" button, as well as operation mode selection Theory, Practice, Independent Work or Tests in any random order.

The learning technology with the use of test tasks provides for the start of work with the EEC from the study of the theoretical part by answering test tasks compiled in a specific section of one or more (two or three) topics. If the student knows the correct answer, he solves the task at once. If, however the student doesn't know the answer to the task or is doubtful about its correctness, he can turn to the theoretical part of the EEC, find the correct answer and mark it with a point in the test task. The peculiarity of the test shell consists in the fact that during the transition from the test Web page to the Theory page, the point is removed from the correct answer of the test shell, and when a person returns to this page, he has to recall the correct answer in previous tasks. Therefore, correct answers to relevant tasks are memorized.

The process of learning theoretical issues starts with reading test tasks selected on a specific topic and finding answers to them in the same source - electronic educational complex (EEC). Each test contains five test tasks. After all tasks are completed, one should press the "Count points" button and summarize. If the student scored a certain number of points, the following recommendations are given: 0-2 points. Either your knowledge of the material is poor or you were simply confused. Try to complete the test again. 3 points. Well, not bad. But not quite good either. 4 points. Good! 5 points. Excellent! Well done!!!

The other topics in the Theory module are studied in a similar way. The study of theoretical issues is completed with the self-testing of knowledge gained through the completion of the "Final Test", which contains fifty test tasks and summing-up: If the testee scored: 0-35 points, then he has poorly learned the material thus far and he needs to complete all tests on the topics once more. 36-40 points - this is a good result, but not quite good 
either. It is expedient that he works with theoretical issues using test tasks once more. $41-45$ points - the student did a good job, but it could have been even better. 46-50 points. Excellent! Well done!! Way to go!!!

As can be seen from the analysis of the number of test tasks on the topics (ten tests, five tasks in each test) and the final test (fifty test tasks), the tests are not identical. This circumstance was introduced in the EEC so that students will find answers not only in the electronic complex itself, but also the list of references which is contained in the electronic textbook. Furthermore, they can take advantage of the search for answers on the Internet.

The mark for the completion of the final test is given not on the day on which the tests on the topics and the selftesting of a student were completed, but is postponed approximately for one or two weeks (in the next lesson), so that knowledge gained during the completion of tests on the topics were deeply-rooted and reinforced in memory. In addition, this allows students to prepare more carefully to the scoring testing based on the final test (by means of "self-testing"). The control final test differs from self-testing in that the time for completion is limited to 10 minutes for all 50 tasks.

\section{Conclusions}

After the study of theoretical issues is completed, the students start solving tasks presented in the Practice module. The learning technology in this module provides for the consideration of the task solving sequence, learning of formulas used and achievement of the result. At all stages of practical work, the students can test themselves using answers presented in the EEC.

Having coped with the solution to the first task of practice on the topic "Short-term and long-term goals of the enterprise", the students proceed to the Independent Work module and do their first independent work on the same topic and solve a similar task, but this time without prompts in the form of the task solution algorithm. Therefore, the knowledge and skills gained in the completion of training exercises, are reinforced. Having completed their first independent work, the students return once more to practical tasks on the topic 2 , upon completion of which they proceed to independent work 2 etc.

The student submits each independent work to the teacher, who assesses its quality, comments on the errors and provides an opportunity to fix them. The overall score of the work with the electronic educational complex is a composite of the score for the completion of the final test: EXCELLENT - if there are 46-50 correct answers to test tasks; GOOD - if there are 41-45 correct answers to test tasks; SATISFACTORY - if there are 36-40 correct answers to test tasks; UNSATISFACTORY - when the number of correct answers to test tasks is less than 36 , and also, according to the average scoring, for all independent works.

When the electronic educational complex was being created, a fairly large volume of educational methodical material was examined in detail both in the testing and in the electronic alternative. Part of these sources is presented below: Asaul (2008), Blank (2007), Dontsova (2010), Kovaleva (2008), Kovalev (2007), Kovalev (2013), Kogdenko (2011), Maleeva (2009), Nikiforova (2010), Rozanova (2009), Stoyanova (2003), Sharp et al. (2001), Sheremet and Negashev (2008).

\section{Bibliographic References}

Androshchuk, EV, Sofyina, EV, Dyachkov, V.P. (2018). Maximizing the profitability of agricultural enterprises in the región. Retrieved from: http: //euk.vgsha.local/FMb/1/glav.html.

Asaul, A.N. (2008). Basics of business in the securities market Textbook. St. Petersburg, ANO "IPEV". 
Basova, A.V., Sofyina, E.V., Dyachkov, V.P. (2018). The most important financial management tools - financial analysis and control. Retrieved from: http: //euk.vgsha.local/euk/FMb/2/glav.html.

Blank, I.A. (2007). Financial management: Textbook / I.A. Form. - 2nd ed., Pererab. and add. Kirov: Elga, Nick Center.

Dontsova, L.V. (2010). Analysis of financial statements: Textbook. Manual. Moscow. BUSINESS and SERVICE.

Dyachkov, V.P. (2012). The concept of e-learning course. Modular structure of construction and ways of working with it. V.P. Dyachkov; Information technology in economics, management, education. Materials scientific and methodical conference. Collection of scientific papers. Kirov: Vyatskaya State Agricultural Academy, 2012.

Dyachkov, V.P. (2015). Electronic educational complex, as an effective means of teaching students in higher education. Sat. scientific st. "Innovative economic development of the economy: entrepreneurship, education, science”; redcol. TV Borzdova (ed.) [And others]. Minsk: GIUST BSU.

Dyachkov, V.P. (2018). The system of electronic tests on electronic educational complexes. Retrieved from: https://www.beclever.h1n.ru.

Kogdenko, V.G. (2011). Economic analysis: Textbook. For students, 2nd ed., Pererab. and add. - Moscow, UNITY-DANA.

Konysheva, M.Ye., Sofyina, E.V., Dyachkov, V.P. (2018). Management of cash flows of agricultural enterprises of the región. Retrieved from: http: //euk.vgsha.local/euk/FMb/6/glav.html.

Kovalev, V.V. (2007). Fundamentals of the theory of financial management: Tutorial. Moscow, PROSPECT.

Kovalev, V.V. (2013). Financial management: Theory and practice. Moscow, Prospect.

Kovaleva, V.V. (2008). Investment: Tutorial. Moscow, Prospectus.

Listopad, N.V., Sofyina, E.V., Dyachkov, V.P. (2018). Financial relations of agricultural enterprises of the region with individual business entities. Retrieved from: http: //euk.vgsha.local/euk/FMb/7/glav.html.

Maleeva, Yu.V. (2009). Comprehensive economic analysis of economic activities: Tutorial / Yu.V. Maleev. Moscow, KnoRus.

Naumova, A.A., Sofyina, E.V., Dyachkov, V.P. (2018). Management of solvency and financial risks of agricultural enterprises of the región. Retrieved from: http: //euk.vgsha.local/euk/FMb/8/glav.html.

Nikiforova, V.D. (2010). Securities market. St. Petersburg, Publishing house of St. Petersburg State University of Economics and Finance.

Polushina, Yu.N., Sofyina, E.V., Dyachkov, V.P. (2018). Managing the circulation of fixed capital of agricultural enterprises of the región. Retrieved from: http: //euk.vgsha.local/euk/FMb/9/glav.html.

Rozanova, N.M. (2009). Economic analysis of firms and markets: Tutorial. Moscow, UNITY-DANA.

Rykova, L.S., Sofyina, E.V., Dyachkov, V.P. (2018). The choice of forms and directions of financing enterprises in the agricultural sector of the región. Retrieved from: http: //euk.vgsha.local/euk/FMb/10/glav.html. 
Semenova E.L., Sofyina E.V., Dyachkov V.P. (2018). The function of financial management as a management system of agricultural enterprises in the región. Retrieved from: http:

//euk.vgsha.local/euk/FMb/11/glav.html.

Sharp, W., Gordon, A.J., Bailey, D. (2001). Investments: Textbook. Moscow: INFRA-M.

Sheremet, A.D., Negashev, E.V. (2008). Methods of financial analysis of the activities of commercial organizations: Textbook. 2nd ed., Pererab. and add. - Moscow: INFRA-M.

Stoyanova, E.S. (2003). Financial Management: Theory and Practice, 5th ed. - Moscow, Publishing house "Perspective"

Vidyakina, A.S. (2018). Managing the formation of profits of agricultural enterprises in the region. Retrieved from: http: //euk.vgsha.lo-cal/euk/FMb/4/glav.html.

Vyrupaeva, N.S., Sofyina, E.V., Dyachkov, V.P. (2018). Cost management of agricultural enterprises in the region [Electronic resource] / N.S. Vyrupaeva, E.V. Sofyina, V.P. Dyachkov. Retrieved from: http: //euk.vgsha.local/euk/FMb/5/glav.htmlю

Weizner, Yu.A., Sofyina, E.V., Dyachkov, V.P. (2018). Efficiency of pricing policy of enterprises of the agroindustrial complex of the región. Retrieved from: http: //euk.vgsha.local/euk/FMb/3/glav.html.

Esta obra está bajo una Licencia Creative Commons

Attribución-NoCommercial 4.0 International

\section{(c) $\mathrm{BY}-\mathrm{NC}$}

